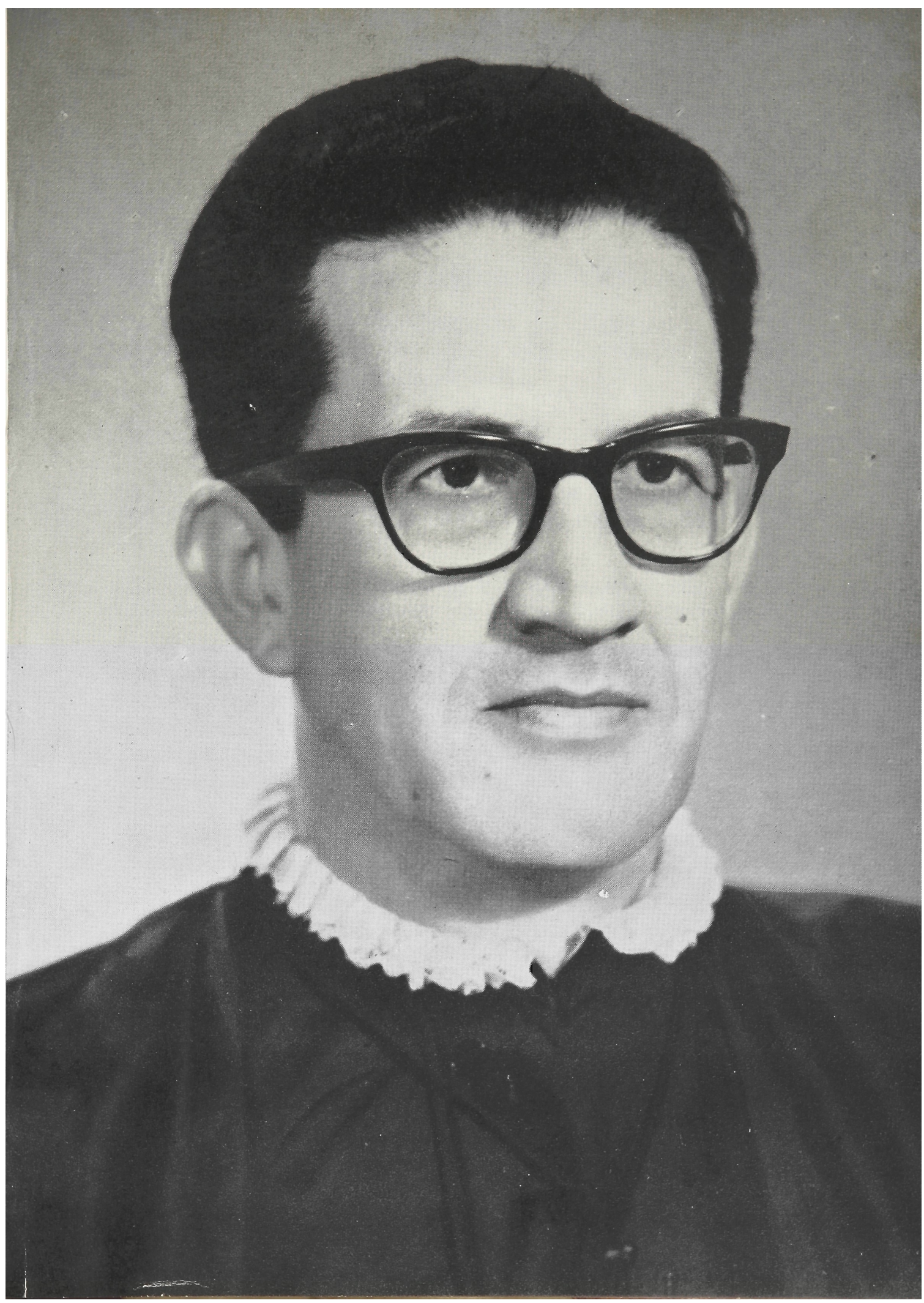




\section{Novo titular da cátedra de Medicina Legal - Dr. João Baptista de Oliveira e Costa Júnior.}

O Dr. João Baptista de Oliveira e Costa Júnior, filho do Dr. João Baptista de Oliveira e Costa e de D. Maria Piedade Nuclério de Oliveira e Costa, nasceu nesta Capita] no dia 10 de abril de 1910.

Fêz os cursos preliminar e ginasial, no Colégio São Luís desta cidade, recebendo na época diversos prêmios.

Em 1927 ingressou na Faculdade de Medicina da Universidade de São Paulo após brilhantes exames de seleção; aprovado em tôdas as séries do curso, defendeu tese de doutoramento em janeiro de 1933 sôbre assunto da medicina legal, cujo título foi: Contribuição para o estudo das linhas brancas datiloscópicas e do seu valor na identificação. Aprovado com distinção, colou grau sòmente em maio daquele ano, devido a acontecimentos políticos conseqüentes à revolução constitucionalista.

Em maio de 1934, após concurso, foi nomeado médico legista regional de Casa Branca, desempenhando êsse cargo até setembro de 1941, data em que foi promovido para o Gabinete Médico Legal da Capital do Estado, onde esteve em exercício até junho de 1956.

Em 1945, prestou concurso à livre-docência de Medicina Legal da Faculdade de Medicina da Universidade de São Paulo, tendo sido aprovado unânimemente pelos membros da Comissão julgadora. Apresentou, nessa ocasião, a monografia intitulada, Contribuição para o estudo da histologia 
do hímen e seu valor médico legal. Foi então incumbido de parte do curso teórico da mesma cadeira.

Em 1949, foi nomeado professor catedrático de medicina legal da Faculdade Paulista de Direito da Pontifícia Universidade Católica de São Paulo, atividade que vem exercendo sem interrupção.

Em 1950, a convite do Grão-Chanceler da Pontificia Universidade Católica, integrou a comissão de seleção de professôres da novel Faculdade de Medicina de Sorocaba, tendo sido anteriormente indicado para professor de medicina legal dessa Faculdade; exerceu essa função docente desde aquela data até setembro de 1962. Em 1955 foi nomeado diretor dêsse mesmo Instituto e reconduzido por dois períodos, desempenhando o cargo até a presente data.

Regeu também a cadeira de medicina legal da Faculdade de Direito da Universidade de Campinas, desde a sua fundação até março de 1963.

Em 1959, prestou concurso à livre-docência de Medicina Legal na Faculdade de Direito da Universidade de São Paulo, defendeudo a tese: A tuberculose pulmonar $e$ o acidente do trabalho. Nesse mesmo ano, foi eleito Conselheiro do Conselho Regional de Medicina do Estado de São Paulo (Tribunal de Ética Médica), para o exercício de cinco anos.

Em 1962, a 8 de junho, passou a reger a cadeira de Medicina Legal da Faculdade de Direito da Universidade de São Paulo, vaga com a aposentadoria compulsória do seu titular, o notável professor Dr. Antônio Ferreira de Almeida Júnior.

Além dessas atividades, exerceu também cargos de relevância na administração universitária, tais como, membro do Conselho Universitário da Pontifícia Universidade Católica de São Paulo, do Conselho Técnico Administrativo das Faculdades, Paulista de Direito e de Medicina de Sorocaba.

Foi também membro de comissões julgadoras de concursos à cátedra e livre docência de Medicina Legal, realizados na Faculdade de Medicina de São Paulo, na Fa- 
culdade de Direito de Pôrto Alegre e na Faculdade de Medicina de Recife.

E ainda sócio honorário do Círculo de Médicos Legistas de Rosario (Argentina) e da Sociedade Argentina de Sexologia, Biotipologia y Eugenia; sócio titular da Sociedade Paulista de História da Medicina e da Sociedade de Medicina Legal e Criminologia de São Paulo, tendo sido secretário da secção de Medicina Legal dessa última no período de 30 de outubro de 1942 a 30 de outubro de 1943 e recebido o prêmio "Alcântara Machado" de Direito Penal; sócio fundador da Academia Latino Americana de Neurologia, Psiquiatria e Medicina Legal e da Ordem dos Médicos Legistas do Brasil, da qual foi eleito secretário geral quando de sua fundação.

\section{Bibliografia.}

E a seguinte a bibliografia do prof. Dr. Costa Júnior:

1. Contribuição para o estudo das "linhas brancas dactiloscópicas" $e$ do seu valor na identificação - Tese de doutoramento - Aprovada com distinção em 17 de março de 1933.

2. Sôbre um caso interessante de morte após injeção de neosalvarsan em colaboração com o Prof. Flamínio Fávero - Arquivos da Sociedade de Medicina Legal e Criminologia de São Paulo, 7: 171 (1936).

3. Valor do exame do conduto auditivo externo nas mortes violentas (Nota casuística), Arquivos da Sociedade de Medicina Legal e Criminologia de São Paulo, 13: 10 (1942).

4. Caranguejos necrófagos - Arquivos da Sociedade de Medicina Legal e Criminologia de São Paulo - 13: 113 (1942).

5. Lesões dos centros nervosos por projéteis secundários de arma de fogo - Arquivos da Polícia Civil de São Paulo - 4: 279 (1942, $2 .^{\circ}$ sem.).

6. Considerações em tôrno de um caso de fulguração - Apresentado à Sociedade de Medicina Legal e Criminologia de São Paulo e publicado nos Arquivos da Polícia Civil de São Paulo — 5: 101 (1943). 
7. Trombose da veia central da retina e acidente do trabalho Apresentado à Sociedade de Medicina Legal e Criminologia de São Paulo e publicado nos Arquivos da Polícia Civil de São Paulo — 5: 101 (1943).

8. Enfisema subcutâneo universal - Arquivos da Polícia Civil de São Paulo - 8: 281 (1944),

9. Tumor do cérebro e intoxicação - Arquivos da Sociedade dé Medicina Legal e Criminologia de São Paulo — 15: 98 (1944).

10. Um caso de lesões pessoais, com abortamento e conseqüente homicídio - Arquivos da Sociedade de Medicina Legal e Criminologia de São Paulo — 15: 126 (1944).

11. Ausencia congénita de hímen, comprobación histológica Interpratación embriogenética - Em colaboração com HILAÁRIo Veiga DE CARvalHo - Revista de Medicina Legal y Jurisprudencia Médica - 9: 1 (1945).

12. Contribuição para o estudo da histologia do hímen e seu valor médico-legal - Tese apresentada à Faculdade de Medicina da Universidade de São Paulo para concurso à livre-docência 1945 - São Paulo.

13. Incapacidade parcial e permanente da mastigação - Nota casuística - Arquivos da Polícia Civil de São Paulo - 9: 265 (1945).

14. Aneurisma traumático da artéria subclávia direita - Costela cervical - Em colaboração com H. VeIGA DE CARvalHo - Arquivos da Polícia Civil de São Paulo - 10: 243 (1945).

15. Atrofia regional da pele e acidente do trabalho - Arquivos da Sociedade de Medicina Legal e Criminologia de São Paulo - 16: 101 (1945).

16. Um suposto estupro - Arquivos da Sociedade de Medicina Legal e Criminologia de São Paulo - 17: 52 (1946).

17. Tuberculose - Acidente tipo - Arquivos da Polícia Civil de São Paulo - 12: 197 (1946, 2.0 sem.).

18. Pseudo-hermafroditismo androginóide irregular - Apresentado à Sociedade de Medicina Legal e Criminologia de São Paulo (1946).

19. Lesão da medula por instrumento pérfuro-cortante - Arquivos da Polícia Civil de São Paulo - 134: 189 (1947).

20. Tumor de células gigantes e acidentes do trabalho - Em colaboração com H. Veiga de CARvalho - Arquivos da Polícia Civil de São Paulo - 14: 143 (1947).

21. Lepra e acidente do trabalho - Arquivos da Sociedade de Medicina Legal e Criminologia de São Paulo - 19: 5 (1948).

22. Surdez e paralisia do nervo facial periférico - Acidente do trabalho - Arquivos da Sociedade de Medicina Legal e Criminologia de São Paulo - 19: 76 (1948). 
23. Sevícia (Nota casuística) - Apresentado à Sociedade de Medicina Legal e Criminologia de São Paulo (1948).

24. Das lesões corporais - Trabalho premiado pela Sociedade de Medicina Legal e Criminologia de São Paulo - Prêmio Alcântara Machado - 1949.

25. Comectomia (crime de injúria) - Apresentado à Sociedade de Medicina Legal e Criminologia de São Paulo - (1950).

26. Das impressões labiais - Apresentado à Sociedade de Medicina Legal e Criminologia de São Paulo (1950).

27. Perigo de vida prolongado - Apresentado à Sociedade de Medicina Legal e Criminologia de São Paulo - (1950).

28. Aspecto bio-psicológico do projeto "Nelson Carneiro" (casamento) - Apresentado à Sociedade de Medicina Legal e Criminologia de São Paulo e Transcrito nos Anais da Câmara Federal de Deputados.

29. Antecipação da morte e acidente do trabalho - Anais do 1. Congresso Brasileiro de Medicina Legal e Criminologia de São Paulo - 2: 207 (1954).

30. Alguns aspectos da medicina legal - Aula inaugural na Faculdade de Medicina de Sorocaba em 10-3-1955 - Revista da Universidade Católica de São Paulo - 7: 39 (junho 1955).

31. Tuberculose e função pulmonar - Em colaboração com os Drs. Diogo Pupo Nogueira e José Meira Cardoso.

32. A tuberculose pulmonar e o acidente do trabalho - Monografia para concurso à livre docência de Medicina legal na Faculdade de Direito da Universidade de São Paulo.

Apresentou, também, os seguintes trabalhos ao Departamento de Medicina do Trabalho da Associação Paulista de Medicina:

33. Varicocele e trabalho (ponto de vista do médico legista) Reunião de 2 de abril de 1955 - Revista da Associação Paulista de Medicina - 46: 311 .

34. As sinusites na indústria (ponto de vista do médico legista) - Reunião de 26 de maio de 1954.

\section{Posse da cátedra de Medicina Legal.}

Com o valioso cabedal de títulos e de trabalhos publicados, submeteu-se o Dr. Costa Júnior ao concurso para a cátedra de Medicina Legal. Com o brilhantismo de cos- 
tume venceu a tôdas as provas, defendendo a tese: Aspectos médico-legais da anestesia, monografia com 956 páginas.

Nomeado para a cátedra, tomou posse em sessão solene da Congregação presidida pelo Sr. Diretor, Prof. Dr. Luis Eulalio de Bueno Vidigal, a 6 de agôsto do corrente ano. Introduzido no recinto pelos professôres Cardoso de Mello Neto, Ernesto de Moraes Leme e José Carlos de Ataliba Nogueira foi saudado em nome da Congregação pelo Prof. Dr. Washington de Barros Monteiro, e em nome dos estudantes pelo orador oficial do Centro Acadêmico XI de Agôsto, Sr. Rui Flávio Guião.

Saudação do Professor Dr. Washington de Barros Monteiro.

"Recebi do Exmo. Sr. Diretor desta Faculdade, professor Luis Eulalio de Bueno Vidigal, a honrosa incumbência de saudar, em nome da Congregação, o nôvo professor de Medicina Legal, dr. João Baptista de Oliveira e Costa Júnior, no instante em que assume o cargo para o qual acaba de ser nomeado. Desincumbo-me do mandato com grande satisfação, porquanto, ao novo catedrático me vinculam antigos, estreitos e sinceros laços de amizade e admiração.

Realmente, foi em 1935 que vim a conhecer o dr. João Baptista de Oliveira e Costa Júnior. Nesse ano, havia ocorrido um crime de homicídio na cidade de Cajurú, onde exercia as funções de delegado de polícia, e o dr. Costa Júnior, na qualidade de médico legista da Delegacia Regional de Casa Branca, havia sido convocado para a autópsia da vítima.

Guardo ainda, em meio às minhas reminiscências, a lembrança dêsse primeiro contacto, em que me ficou a impressão da segurança e da competência do perito oficial, que assim prestava à justiça as luzes do seu saber e da sua experiência.

Mas existe um pormenor que desejo agora acrescentar, porque bem demonstra a excelência de sua formação, reve- 
lada por uma só frase. Durante a diligência, que eu acompanhava pessoalmente, fêz o dr. Costa Júnior esta confissão: quanto mais examino o corpo humano tanto mais me convenço da existência de Deus.

Disse Julien Green, certa feita: tenho a felicidade da fé, todo o resto é noite. Como o autor do Leviathan, o dr. Costa Júnior também construiu sua vida sôbre a fé, subtraindo-se assim ao tormento da incredulidade, perante a qual o mundo é um caos, o homem um enigma e a vida uma desgraça.

Depois dêsse primeiro encontro, de que conservei tão indelével recordação, que os anos não conseguiram apagar, cruzaram-se de novo os nossos caminhos em 1949, na Faculdade Paulista de Direito da Pontifícia Universidade Católica de São Paulo. Precisamente naquele ano juntos iniciamos nosso magistério na jovem escola de direito.

Desde logo se teve notícia da alta proficiência do professor de Medicina Legal, em que avultava, dentre outras virtudes, ao lado da seriedade de seu magistério, a limpidez plana e fluente de suas aulas, e que é, no meu entender, a qualidade precípua de uma perfeita manifestação do pensamento.

O professor deve sua ciência, tôda a sua ciência, aos alunos. O curso do professor há de ser como um livro aberto ante os olhos de seus discípulos. Assim foi e continua sendo, naquela escola, o ensino do dr. Costa Júnior, que sempre se esforçou para estar ao nivel de seus ouvintes, abrindo-lhes a inteligência e modelando-lhes os corações, num verdadeiro apostolado de cultura e de ciência.

Pela terceira vez, agora nesta Faculdade, tornamos a encontrar-nos. Por certo, jamais poderia passar pelas nossas mentes, naquele longínquo episódio de Cajurú, no comêço de nossas atividades profissionais, que um dia tomariamos assento no mesmo doutoral e que seria eu até quem lhe daria as boas vindas, por designação honrosa desta Congregação.

Mas não é devaneio, nem se trata de imaginação e aqui estamos, neste dia festivo, para bater-lhe palmas no ato de 
sua posse como professor catedrático de Medicina Legal da Faculdade de Direito da Universidade de São Paulo. Assim como Deus põe uma sorte em cada homem, põe também um destino em cada uma dessas cadeiras. E se existe cadeira predestinada é a de Medicina Legal.

Primeiro, foi Amâncio de Carvalho, professor de 1891 a 1925, que foi mestre de meu pai, e que a êle se referia de modo tão afetuoso, com o mesmo carinho com que o filho fala do próprio pai. Depois, Alcântara Machado, meu professor de Medicina Pública, como outrora se denominava a cadeira, sempre grave, severo, circunspecto, algumas vêzes irônico, chegando mesmo a infundir, temor, mas, conspícuo pela eloqüência e pela veracidade, cujas aulas ouvíamos com o maior encantamento. Em seguida, Almeida Júnior, meu mestre de história natural no velho Instituto Rio Branco, instalado primeiro na Consolação e depois na rua Maria Antônia, exemplo de professor, pelo seu alto senso do dever, pela exação que sempre imprimiu em todos os seus atos e que tem o supremo dom de ganhar os corações. Agora é a vez do Dr. Costa Júnior, que será, por certo, um digno continuador de tão eminentes mestres, porque, para lanto, não lhe faltam capacidade e talento.

Essa investidura, que hoje testemunhamos, solenizamos e aplaudimos, não só representa um lance de grande valor, sublinhado através de provas públicas, sem dúvida árduas e penosas, exigidas num concurso, como encerra uma profunda lição. Para o novo professor, a jornada foi longa, foi difícil, mas havia um só caminho e êle trilhou-o sem receio. Naturalmente houve tropeços, mas êstes contam pouco nos desígnios de uma criatura decidida, sinceramente animada do desejo de vencer.

Assim, no exame vestibular da Faculdade de Medicina realizado em 1927, com dezesseis anos apenas, alcançou o dr. Costa Júnior a segunda colocação, em meio a centenas de candidatos. Pelo dedo já se poderia conhecer o gigante, como por uma vértebra Cuvier descobrira o mastodonte. 
Apenas formado, no ano de 1933, defendeu tese, sendo aprovado com distinção.

Pouco depois, mediante concurso de provas, conquistou o cargo de médico legista da Polícia Civil, sendo nomeado para a Delegacia Regional de Casa Branca, onde permaneceu até 1941, quando foi removido para esta Capital, vindo a aposentar-se nesse cargo em 1956.

Mas o dr. Costa Junior não se detivera, a perseverança sempre foi sua constante e por isso soube com côres brilhantes iluminar sua existência: assistente da cadeira de Medicina Legal da Faculdade de Medicina em 1942, livre-docente dessa mesma cadeira, e na mesma escola, em 1945, professor catedrático da Faculdade Paulista de Direito em 1949, professor catedrático da Faculdade de Medicina de Sorocaba, em cuja direção se encontra desde 1955, professor da Faculdade de Direito de Campinas, livre-docente desta Faculdade, desde 1959 , ascende agora à respectiva cátedra, que acaba de conquistar após brilhantíssimo concurso.

Outros muitos títulos poderia ainda acrescentar a essa luminosa constelação de credenciais, granjeados à custa de tenacidade e de saber, aliados a uma perfeita integridade, que é, indubitàvelmente, a obrigação mais absoluta do indivíduo para consigo mesmo.

Como se vê, o dr. Costa Júnior percorreu longo e rude caminho, porém, abeberado nas fontes de uma energia infinita, soube chegar ao fim e êsse fim valeu a pena. Não pode haver maior galardão que o de professor nesta $\mathrm{Fa}$ culdade, que é escola e é templo.

Quando a gente envelhece começa a meditar e me persuado de quão exata era a frase de um aluno, ao cumprimentar-me quando obtive o lugar de professor: eis a verdadeira imortalidade, ser professor na Faculdade de Direito de São Paulo.

Mas essa é a lição que se extrai desta solenidade: entre todos os caminhos que conduzem à glória, o trabalho não é sòmente o mais nobre, como também o mais seguro. Tal é 
a lição que ministra o professor Costa Júnior ao ascender à sua cátedra.

Queira, eminente professor, em meu nome, em nome do Exmo. Sr. Diretor, assim como de todos os professôres desta Casa, com as nossas efusivas felicitações, aceitar os votos de bomêxito nesta nova fase de sua existência, iniciada sob tão brilhantes auspícios. A Faculdade é sua e ela muito espera de seu saber e de sua ilustração".

Oração do Professor Dr. João Baptista de O. e Costa Júnior.

Após a saudação do Prof. Barros Monteiro, o novo catedrático proferiu a seguinte oração:

"Não sei, neste instante, traduzir o estado d'alma que me agita e acelera o coração. Há momentos, como êste, ao dirigir-me à egrégia Congregação desta Faculdade e aos meus diletos alunos, em que a voz se corporifica e cria forma, tremendo de emoção e apagando-se de temor.

A inteligência permite-nos compreender a razão das coisas e possibilita adaptarmo-nos às condições da vida; a vontade dá-nos a soberania e o direito ao prêmio; mas tudo isso sem afeto é descolorido, insensível e não percebe o sabor dos acontecimentos vividos e imaginados. $\mathrm{E}$ mais. Deverá, também, existir o ideal por vetor, que transforma o pensamento na vivência permanente e produtiva, ideal êsse que desperta o coração e impulsiona o homem para os seus grandes cometimentos. Certo, porém, nem sempre as condições são propícias ao objetivo colimado, pois, ainda quando êle é dotado de inteligência e cultura privilegiadas - e apesar de esbanjar esforços - poderá não conseguir resultados que lhe sejam favoráveis. Há como um conjunto de fatores, alguns imponderáveis, outros imprevisíveis, que não lhe possibilitam realizar os ideais a longo tempo acariciados. Que importa? se o sonho é algo imanente que compensa as desilusões e justifica a incompreensão da vida! 
Não contesto que, no meu caso particular, a cátedra de Medicina Legal da Academia do Largo São Francisco não se me afigurasse como uma vaga esperança a povoar-me o espírito irrequieto. Sentia o desejo, via o luzir do prêmio e antegozava ingênuamente a vitória acalentada; entretanto, tais eram a honra e o vulto do galardão, que me parecia apenas uma perspectiva distante, quase impossível e cuja idéia flutuava como um devaneio próprio das imaginações juvenis.

Pertencer à Congregação desta Faculdade; ter como companheiros de magistério seus ilustres mestres; lecionar aos jovens herdeiros do heroismo e das glórias dos que lhes precederam no tempo; lembrar dos professôres que no passado pontificaram em suas cátedras; saber que nesta escola, ecoam ainda as maiores e mais eloqüentes vozes do pensamento e das reivindicações nacionais, parecia-me ousadia ou, até mesmo, pecado acreditar que um dia também pudesse eu nela ingressar; motivo porque a realidade presente me atordoa e confunde, fazendo-me pensar na miragem dos viandantes pelos desertos.

Há fatos que se não esquecem; ficam retidos na memória e gravados no coração como marcos indeléveis no caminho da vida. Dentre muitos destaco, pela emoção que me foi dado sentir, dois dêles com significados diferentes, é verdade, diversos nos cenários e nas circunstâncias verificadas, porém, idênticos nas suas reações e no alvorôço da minha alegria. O primeiro na ordem cronológica, quando, transferindo minha residência de uma cidade do interior paulista para esta Capital, fui surpreendido com o páteo da estação lotado de clientes humildes, desprotegidos da fortuna mas que faziam questão de levar o abraço de despedida ao médico e amigo certo. 0 outro, muito recente, agora, neste momento, ao ver-me alçado às alturas inacreditáveis no passado, pela investidura na cátedra de Medicina Legal desta Faculdade de Direito e que chega, até mesmo, a trazer-me o receio de que isso possa transformar a modéstia, que sempre procurei cultuar, substituindo-a pelo orgulho 
que hipertrofia os defeitos e destrói os melhores sentimentos. E não é para temer-se tal transformação, quando aqui ainda se ouvem o rítmo do cantar de seus poetas e o verbo tonitroante de seus tribunos; quando aqui ainda se auscultam os ensinamentos e se testemunham os exemplos edificantes de seus mestres inigualáveis? E quando aqui ainda se vêem a bandeira da liberdade e a chama sagrada do mesmo ideal, que exalta e enobrece a sua mocidade acadêmica, na sucessão ininterrupta das gerações que passam?

Quero, portanto, manifestar os meus agradecimentos a todos aquêles que contribuiram para a minha formação científica, permitindo-me um dia bater às portas desta Academia. A começar pelos padres jesuitas, mestres que sabem estabelecer a união entre professôres e alunos, baseada na verdadeira amizade e no mútuo respeito.

Depois, na Faculdade de Medicina de São Paulo, a Ovídio Pires de Campos e Flamínio Fávero. Ao primeiro, já falecido, que me transmitiu o conhecimento da clínica médica e ao segundo que me iniciou na Medicina Legal e, mais tarde, de forma afável, acolhedora e paternal, convidou-me para seu auxiliar de ensino, dando-me a oportunidade de prestar concurso para a docência-livre na sua cadeira, isto é, abrindo-me o caminho para o magistério superior.

Tenho, também, uma dívida de gratidão para com o grão-chanceler da Pontifícia Universidade Católica de São Paulo, o meu ilustre e grande amigo Cardeal Motta, que sempre me distinguiu com a sua amizade e confiança, entregando-me a direção da Faculdade de Medicina de Sorocaba por três mandatos sucessivos, quando anteriormente me havia designado para reger a cadeira de Medicina Legal da mesma Faculdade de Medicina e da Faculdade Paulista de Direito.

Não posso ainda esquecer o nome do Magnifico Reitor da Universidade Católica de Campinas, Monsenhor Dr. Emílio José Salim, por ter-me incluído como um dos professôres da sua Faculdade de Direito. 
Mas não é só. Conservo comigo as melhores recordações do tempo que exerci as funções de perito do Serviço Médico Legal do Estado, onde o fraternal ambiente de trabalho oferecia as condições necessárias ao estudo e à pesquisa científica.

Com todos êsses antecedentes não seria razoável continuar a avançada, tendo os ventos favoráveis e soprando na mesma direção?

Foi assim que pensei e melhor decidi.

$\mathrm{E}$ a verdade aí está para demonstrar que não foram inúteis os meus esforços, nem perdido o tempo da preparação.

Sei, perfeitamente, da responsabilidade que me pesa sôbre os ombros: substituir o Prof. Almeida Júnior não é apenas missão difícil senão tarefa impossível. Mestre consagrado na expressão mais pura do têrmo; figura ímpar de educador e de didata primoroso; dotado de invulgar capacidade de trabalho e de larga visão não sòmente acêrca dos temas médico-legais, como, também a respeito do ensino em quaisquer de seus graus. Tive a rara ventura de acompanhar o seu curso depois que conquistei a livre docência nesta Faculdade. Nunca imaginei que pudesse aprender tanto, quando já me considerava senhor dos segredos do magistério superior. Foi um encantamento, para mim, ouví-lo expor, com arte e sabedoria, a matéria lecionada, jamais se esquecendo de aproveitar tôdas as oportunidades para estimular, nos alunos, o cumprimento do dever e os mais puros sentimentos de brasilidade. A sua assiduidade era de causar inveja; sempre exigente na observância dos horários e consciencioso na vigilância dos trabalhos escolares. Que personalidade reta e sensível, temperada por fina e agradável ironia! Posso assegurar, com tôda a sinceridade, que apesar de ter sido um interessado direto e candidato confesso à cátedra de Medicina Legal, senti a sua aposentadoria como poucos a poderiam ter sentido. Desejava-a bem mais distante e cheguei mesmo a considerar madrasta a lei que afastava do convívio dos alunos, o mestre de tal 
envergadura cultural e de cuja agilidade mental as palavras brotavam fáceis, agradáveis e coloridas como um verdadeiro caleidoscópio de imagens e pensamentos.

Pode êle vangloriar-se, como poucos, de ter encerrado as suas atividades no magistério superior oficial cercado da admiração de seus colegas e do respeito e carinho de todos os seus alunos, porque foi bom, foi sábio e foi justo.

Reconheço, também, que a cadeira de Medicina Legal desta Faculdade tem, ainda, a exaltá-la o patronato de duas outras figuras exponenciais do magistério superior: Amâncio de Carvalho e Alcântara Machado. O primeiro que a instalou, imprimindo-lhe as diretrizes iniciais, a um tempo em que a sistemàtica do ensino jurídico prendia-se tradicionalmente à teorética e à exagerada valorização da oratória, procurando, na medida de suas possibilidades, dar ao ensino um sentido objetivo que facultasse maior rendimento útil ao aluno. Do segundo, não poderá o tempo ofuscar-lhe a glória. Careço de formação jurídica para apreciá-lo em tôdas as suas dimensões, mas conheço-lhe os estudos de Medicina Legal; o anteprojeto do Código Penal e a literatura que nos legou na pureza de seu estilo, na fascinação de sua forma, na precisão de seus conceitos, na prudência de suas afirmações e, sobretudo, no exemplo de seu amor à Pátria e à terra paulista.

Compreendo, portanto, fàcilmente que as instituições valem mais pelos homens que as compoem do que pelas normas escritas que as regem; estas são símbolos menos expressivos e que se deformam ou alcandoram segundo as pessoas que as executam.

Eis porque sou daqueles a acreditarem que as melhores reformas devem processar-se no próprio homem, na reformulação de suas disposições mais interiores para o aperfeiçoamento do ensino, o que não exclui a melhoria das condições técnicas, a atividade docente por equipes e os grupos de trabalhos práticos, que tornam realidade efetiva os conhecimentos teóricos.

A obrigatoriedade da docência sob a forma de dedicação plena, teòricamente ideal, só se completa com aluno em re- 
gime de tempo integral e com o rigor na seleção dos candidatos ao ingresso nos institutos de ensino superior; todavia, nas condições atuais dos cursos jurídicos poderá não despertar o interêsse dos melhores profissionais, dos mais diferenciados cientificamente, por não se conformarem êles com o cerceamento de sua liberdade cultural, abrindo assim o caminho, até mesmo para os desiludidos ou fracassados, que procurariam no magistério as vantagens que a atividade liberal thes havia negado. Ainda mais. Quando a incerteza do futuro intranqüilizasse o cientista, trazendo-lhe a dúvida de que uma situação instável, por incompreensão ou conveniências estranhas, pudesse afastá-lo da cátedra, conseguida com lutas e méritos, êle se desinteressaria pela carreira universitária, deixando que a posição fôsse disputada pelos menos capazes e, quiçá, mais oportunistas. E não é só. $O$ que na verdade dignifica a cátedra é a liberdade de pensamento sôbre a disciplina lecionada e a certeza de que a sua conquista jamais lhe será usurpada. Entretanto, ela só poderá ser engrandecida por quem tiver a vocação necessária para o magistério; vocação essa que no dizer de Payen é o chamamento para uma vida de sacrifício e abnegação, a qual exige duas condições essenciais: o prazer imenso de transmitir os conhecimentos adquiridos e o amor ao aluno, que representa as suas mais caras esperanças e que traduz o seu próprio ser a refletir os mesmos ideais e idênticos propósitos. É ela, a vocação, a fonte perdulária de água límpida e cristalina que vincula o mestre ao discípulo na continuidade do pensamento e na integração afetiva de recíprocas influências.

Eis porque a escola, apesar de existir em função do aluno, não é apenas o seu corpo discente, mas caracteriza-se, principalmente, pela interrelação entre mestres e discípulos, não interpretada como simples exteriorização verbal e sim como vivência dinâmica no mais autêntico sentido comunitário que a enobrece e dignifica. Ou será assim ou não será escola. Eu, de minha parte, posso dizer que de tal 
modo a tenho compreendido e, na medida de minhas fôrças, melhor a tenho vivido.

A juventude atual sente, como tôda a humanidade, a angústia das incertezas do amanhã; sofre as conseqüências da acirrada luta pela vida, que a afasta da convivência mais intima de seus familiares; percebe os embate da incompreensão; e vê, perplexa, a agitação das idéias e das paixões incontroláveis, que tumultuam a sociedade contemporânea. $\mathbf{E}$ como tudo isso perturba a dinâmica do processo evolutivo da personalidade!

A escola, portanto, não deve ser únicamente o centro de informação cultural mas também o prolongamento na formação integral da mocidade estudiosa. $O$ mestre que omitir êsse sentido não estará cumprindo com os seus deveres para com a Pátria e para com Deus. E o que resultar dessa falha, certamente lhe pesará na consciência. São tão graves as faltas dessa natureza que o insuperável Vieira, já o dissera em mais de um dos seus memoráveis sermões: "Ser-nos-ão de pedir contas mais pelo que deixamos de fazer do que pelo que já fizemos".

A alegria da minha investidura na cátedra de Medicina Legal é, para mim, ainda maior com a resolução do Exmo. Sr. Diretor Prof. Luis Eulálio de Bueno Vidigal, escolhendo o Prof. Washington de Barros Monteiro para saudar-me nesta recepção solene.

Conheço o vosso intérprete há muitos anos. Éramos jovens ainda, recém-formados e pertenciamos ao quadro de funcionários da mesma Secretaria de Segurança Pública, quando se deu o nosso primeiro encontro: êle como delegado de polícia de Cajurú e eu como médico-legista regional de Casa Branca. Vi, logo, naquela ocasião. o brilho de sua inteligência e o que the reservava o futuro. E não me enganei! E o tempo serviu para confirmar as minhas previsões. A sua simpatia e a delicadeza de trato cativaram-me desde o início. Depois solidificamos a nossa amizade na Faculdade Paulista de Direito, onde tive a oportunidade de envaidecer-me ainda 
mais do ilustre amigo, festejado jurista, escritor emérito e mestre erudito. As suas palavras, portanto, teriam, evidentemente, de trazer êsse colorido de bondade, que realça apenas os meus supostos merecimentos, evitando destacar os deméritos que a amizade não reconhece.

Agradeço, pois, com tôdas as veras do coração, a sua generosidade e as palavras amáveis proferidas em sua alocução.

O insondável destino, entretanto, não permite que essa alegria transborde, neste instante, para não fugir à regra inexorável dos acontecimentos humanos. Volvendo o olhar para um dos lados, nesta sala, vejo dois lugares vagos, os quais, para mim, representam a tristeza e a saudade que contrastam com esta festiva solenidade. Um, porque aquela que deveria estar só me afagou um ano apenas, não a tendo siquer conhecido pessoalmente, senão através dos informes familiares, sempre coincidentes acêrca de sua bondade, pois cêdo desapareceu no holocausto mais puro e sacrosanto da maternidade; e o outro, porque o seu ocupante que certamente aqui estaria, também, viajou, para nunca mais retornar, quando mais íntimos e fraternais eram os nossos diálogos, aquêle de quem herdei o nome e que sempre foi motivo de meu justificado orgulho filial. Sei que ambos já no Céu, assistem a êste momento grandioso de minha vida e que, de lá se associam à minha alegria, razão pela qual, desejo agora, nesta evocação afetiva, que é ao mesmo tempo uma prece, pedir-lhes, de mãos postas, que agradeçam a Deus por mim.

Não desejaria, douta Congregação, entrar nesta escola como o vitorioso de uma grande batalha: cabeça erguida, olhar penetrante e envolto de glórias. Não. Esta casa não é um troféu conquistado, onde se cobrem de flores e se exaltam os feitos dos heróis; pelo contrário é, um santuário de civismo, onde se cultuam as tradições da raça e os impostergáveis direitos dos homens.

E não é êste recinto um templo? Não estão ali o altar e a nave? E, por acaso, não estão lá fora os arcos? Então, 
como se poderia nela penetrar senão genuflexo, de cabeça baixa, em atitude de oração, não para receber os louvores que a vaidade exaltam e sim para cumprir uma promessa pela honraria da investidura, pedindo a ajuda necessária para que não faltem as fôrças que me permitam honrar o legado de meus ilustres antecessores, a confiança de meus pares e as esperanças de sua mocidade acadêmica.

Há recintos que se não caracterizam sòmente pelas paredes que os circundam nem pelos portais e janelas que os completam nem tão pouco pelos fins a que se destinam mas, principalmente, pela alma que os presidem e que, na continuidade de sua história, se identificam com a tradição, o civismo e os anseios das gerações na marcha inevitável do tempo. São como o calor que comunica a energia, a seiva que mantém a vida e a sombra que conforta e reanima o espírito. Tenho a certeza de que se a tranqüilidade desaparecer, se o desânimo dominar todos os lares e se a destruição afligir a Pátria, haverá ainda, pelas frinchas de suas estruturas o raio de luz que indicará o novo alvorecer.

Que de melhor se poderia desejar senão que a Universidade não tivesse muros que a segregassem; barreiras que a enclausurassem, nem portões que se abrissem apenas aos favorecidos dos sistemas dominantes? Se assim não fôsse seria preferível que a destruíssemos para erguer o seu estandarte em funeral.

Quando aqui cheguei não era o aventureiro que buscava conquistar o prêmio sem esfôrço mas, sim, o viajor que vinha de longa jornada, calejado na boa peleja e causticado pelos raios do sol, que marcam o caminho percorrido. Sei, portanto, valorizar, e muito, o galardão conseguido, como todos vós, ilustres colegas, o conquistastes, antes de mim e com maior brilho. Sei amar a mocidade desta Academia; sinto orgulho de tê-la bem junto ao coração. Ausculto, neste instante, a sua clarinada pela abolição; vejo-a nas barricadas, lutando pela liberdade; assisto, ufano, à sua marcha gloriosa nos batalhões constitucionalistas, pela implatação da lei contra o caudilhismo que nos humilhava 
e denegria; contemplo-a no seu martírio estóico, derramando o sangue generoso pela Pátria estremecida, ao mesmo tempo que a reverencio na imortalidade de seus heróis. É a mocidade sem vocação para ser escrava; que não admite o aviltamento da pessoa humana, e que é a legítima depositária dos mais belos legados de seus antepassados: a predestinação histórica pela liberdade, o impulso incoercível pelo Direito e o incomensurável sentido de brasilidade. Selam os seus compromissos a voz e o sangue daqueles que se sentaram nos mesmos bancos e que pisaram os mesmos páteos engalanados pelos tradicionais arcos, símbolos da apoteótica alegoria dos sonhos, das lutas, dos sorrisos e das lágrimas das gerações que se perpetuam nos mesmos ideais e nas mesmas esperanças.

Ave, pois, Academia do Largo São Francisco." 